\title{
:

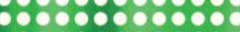

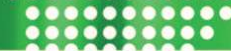

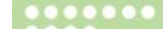
$880^{\circ}$

000

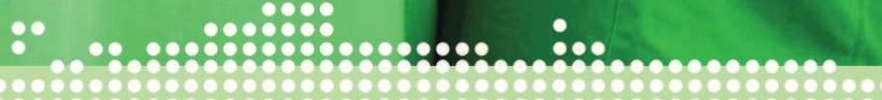

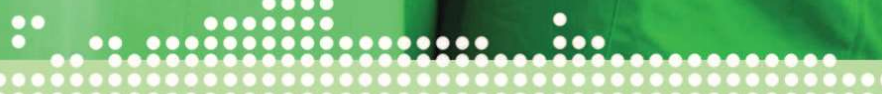

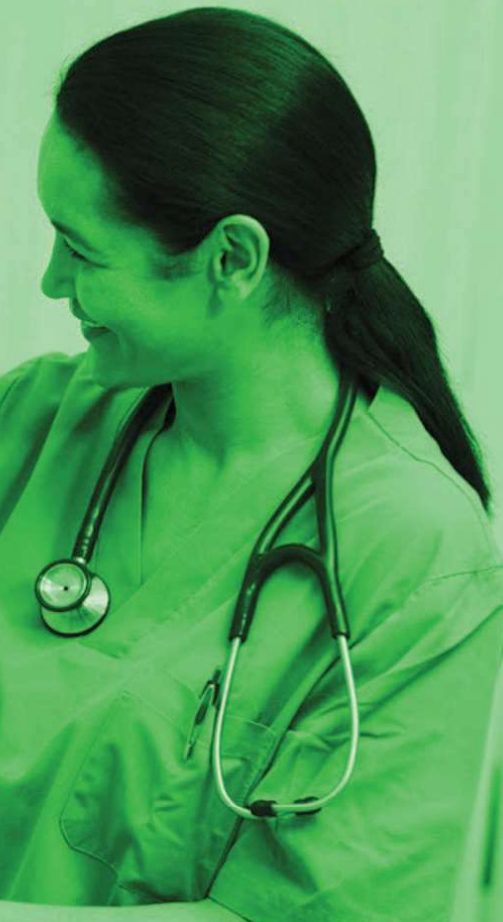

○०
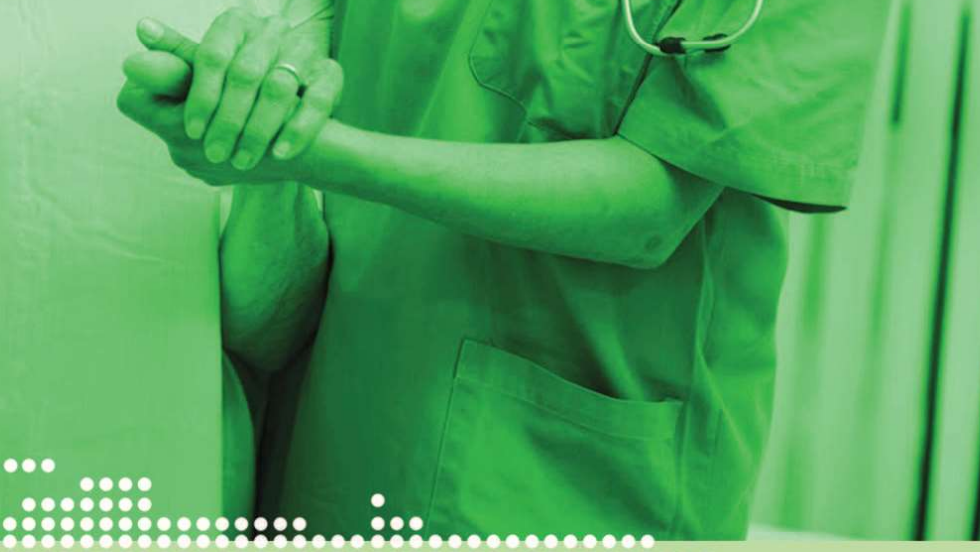

MATERIALY DYDAKTYCZNE

DLA KIERUNKU PIELĘGNIARSTWO

0000000

Andrzej Kryński, Zbigniew Domżał

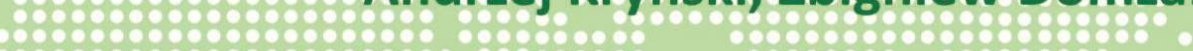

$\$ 00000000000000000000000009000008$

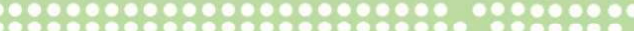

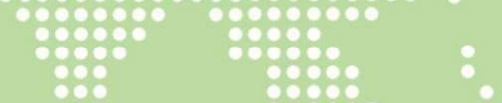

Fundusze Europejskie Wiedza Edukacja Rozwój

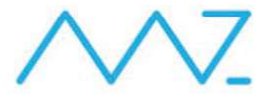

Ministerstwo Zdrowia
Rzeczpospolita

Polska
Unia Europejska

Europejski Fundusz Społeczny 


\title{
Materiały dydaktyczne dla kierunku Pielęgniarstwo
}

\author{
Komunikacja interpersonalna \\ Komunikacja z pacjentem
}

Asertywność w relacjach z pacjentami i współpracownikami

Częstochowa 2019
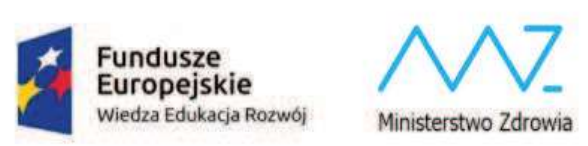

Rzeczpospolita

Polska

Unia Europejska

Europejski Fundusz Spoteczny

Projekt nr POWR.05.05.00-00-0006/18 pt. " Wzbogacenie jakości kształcenia wyższego na kierunku pielęgniarstwo w Akademii Polonijnej w Częstochowie" realizowany w ramach Programu Operacyjnego Wiedza Edukacja Rozwój, Działanie 5.5 Rozwój usług pielęgniarskich 


\section{REDAKCJA NAUKOWA}

Ks. prof. dr. hab. Andrzej Kryński

Prof. dr hab. Zbigniew Domżał

\section{RECENZENT}

dr Agnieszka Szpak

mgr Andrzej Galaidin

Publikacja opracowana w ramach projektu nr POWR.05.05.00-00-0006/18 pt. " Wzbogacenie jakości kształcenia wyższego na kierunku pielęgniarstwo w Akademii Polonijnej w Częstochowie" realizowanego w ramach Programu Operacyjnego Wiedza Edukacja Rozwój, Działanie 5.5 Rozwój usług pielęgniarskich

Nakład: 110 egzemplarzy

ISBN: 978-83-7542-193-4

DOI: $10.32782 / 978-83-7542-193-4$

SERIA WYDAWNICZA: HED/03/03 ZDROWIE, ŚRODOWISKO, ROZWÓJ

C Copyright by Akademia Polonijna w Częstochowie

Wydawnictwo Akademii Polonijnej „Educator”

ul. Pułaskiego 4/6 42-200 CZĘSTOCHOWA

email:wydawnictwo@ap.edu.pl 